\title{
Wybrane aspekty badania kół zębatych metodą prądów wirowych
}

\section{Some aspects of application eddy current method for the gear wheels control}

\section{Streszczenie}

IMP prowadzi od wielu lat prace z zakresu strukturoskopii, defektoskopii i oznaczania naprężeń. W artykule przedstawiono analizę wyników badań kół zębatych metodą prądów wirowych z uwzględnieniem głębokości wnikania.

Celem pracy było przede wszystkim sprawdzenie wykrywalności pęknięć i możliwości oceny stanu naprężeń w wieńcach kół zębatych po procesie hartowania indukcyjnego. Pomiary wykonywano miernikiem Wirotest 302 oraz sondami specjalistycznymi opracowanymi w IMP do badań kół zębatych. Pomiary wykonywano na kołach ze sztucznymi nacięciami i bez nacięć.
Abstract

For many years IMP has been conducting works in the field of structuroscopy, defectoscopy and stress indication. This paper presents the results of the examination of gear wheels using the eddy current method. The purpose of these works was to develop a method of detecting cracks and imperfections of the structure and stresses. Measurements were carried out with the Wirotest 302 measure and specialized probes with different frequency (and different depth of penetration) developed in IMP for examination of gear wheels. The gear wheels with and without artificial defects were used.

\section{Wstęp}

Trwałość kół zębatych zależy m.in. od poprawności wykonania obróbki cieplnej, cieplno-chemicznej i powierzchniowej. Podstawową cechą determinującą jakość kół zębatych z warstwami zahartowanymi indukcyjnie jest grubość tych warstw i brak w nich defektów spowodowanych obróbką mechaniczną i cieplną. technologicznych, ale i w czasie eksploatacji a nawet magazynowania. Jest to układ wielu zmiennych i równoczesnej ocenie należy poddać stan struktury, stan naprężeń oraz obecność pęknięć i mikropęknięć. Pożądane byłoby przewidywanie trwałości eksploatacyjnej kół na podstawie wyników badań nieniszczących, wykonanych w toku produkcji, np. przed i po procesie hartowania indukcyjnego.

IMP prowadzi od wielu lat prace z zakresu strukturoskopii, defektoskopii i oznaczania naprężeń [1]. Przedmiotem badań metodą prądów wirowych relacjonowanych w [2] były koła zębate przed i po procesie hartowania indukcyjnego. Efekty tej obróbki mogą być kontrolowane w sposób jednoznaczny metodą prądów wirowych, przy użyciu Wirotestów produkcji IMP.

Dr hab. inż. Tomasz Babul, mgr inż. Sylwester Jończyk - Instytut Mechaniki Precyzyjnej.

\section{Wybrane przyczyny występowania wad i możliwości ich wykrywania}

\section{Wady struktury, stan naprężeń, znaczenie obróbki powierzchniowej}

W przypadku kół zębatych występują zarówno niejednorodności struktury, jak i gradient naprężeń. W procesie hartowania indukcyjnego uzyskuje się w obrębie wieńca naprężenia ściskające. Wartość tych naprężeń zmienia się z głębokością warstwy. Naprężenia strukturalne spowodowane są zmianą objętości (martenzyt - największa, austenit - najmniejsza). Powstałe naprężenia ściskające, przez powolny ich spadek, przeciwdziałają naprężeniom rozciągającym. Spadek twardości jest spowodowany bezpośrednio przez rosnące naprężenia rozciągające.

Istotną rolę w trwałości eksploatacyjnej kół zębatych odgrywa proces szlifowania. Drgania i ciepło powstające w strefie skrawania powodują zmienną grubość warstwy skrawanej i zmianę rozkładu naprężeń własnych, twardości i struktury warstwy wierzchniej. Uważa się, że oddziaływania cieplne powodują naprężenia rozciągające, a oddziaływania mechaniczne - ściskające. 
Pole naprężeń w warstwie wierzchniej charakteryzuje się dużymi gradientami naprężeń. Naprężenia rozciągające mogą prowadzić do pęknięć i trudno wykrywalnych mikropęknięć warstwy wierzchniej. Niewłaściwe parametry szlifowania prowadzą także do wzrostu ilości austenitu szczątkowego [3].

\section{Badania metodą prądów wirowych}

Zadaniem jest kontrola jakości warstw zahartowanych: imperfekcji struktury, obecności pęknięć i mikropęknięć, ocena stanu naprężeń. Te trzy zmienne można kontrolować metodą prądów wirowych. Trudnością jest odróżnianie sygnałów od nich pochodzących. Naprężenia wymagają badania w cienkich warstwach powierzchniowych, pozostałe - pomiarów na większej głębokości wnikania. Pęknięcia powodują zmianę przewodności elektrycznej (ostry sygnał braku materiału), zmiany struktury przejawiaja się zmiana przenikalności magnetycznej i przewodności elektrycznej, naprężenia powodują zmianę przenikalności magnetycznej. Badania wymagają więc doboru głębokości wnikania do rodzaju badania.

Standardowa głębokość wnikania, obliczana według wzoru:

$$
\delta_{0}=\frac{500}{\sqrt{f \cdot \gamma \cdot \mu_{r}}}
$$

jest przydatna przy przypızonycn oszacowaniach. Już w latach 50. XX w. i następnych uważanox, że głębokość wnikania zależy od parametrów próbki, konstrukcji cewek, współczynnika wypełnienia, częstotliwości pola wzbudzającego, czułości użytego przyrządu i natężenia pola wzbudzającego [4].

W przypadku materiałów magnetycznych struktura i twardość wpływają silniej na przenikalność magnetyczną niż na przewodność, toteż do kontroli struktury i twardości jest przydatny Wirotest 302 - jako przyrząd nieczuły na fazę. O możliwości uzyskiwania pożądanych głębokości wnikania decydują tu nie tylko właściwości badanego materiału i zastosowana częstotliwość pomiarowa, ale także konstrukcja miernika i sond pomiarowych.

\section{Wyniki badań metodą prądów wirowych}

\section{Metodyka pomiarów}

Zestaw pomiarowy składał się z miernika (Wirotest 302) i sondy przenoszącej impuls na powierzchnię badaną oraz odbierającej sygnał. Wskazania Wirotestu sygnalizują miejsca wadliwe jako impuls wskazań w miejscu uszkodzenia (pęknięcia) albo odchylenie wskazań od wartości przyjętej za prawidłową, np. od odczytu dla sąsiednich zębów (metoda samo-porównawcza).
Tablica I. Głębokość nacięcia w wybranych zębach

Table I. Cuts depth in selected teeth

\begin{tabular}{|l|c|c|c|c|c|c|}
\hline Numer zęba & $15^{*}$ & 22 & 26 & 29 & 32 & 36 \\
\hline Głębokość nacięcia, mm & 1,5 & 0,1 & 0,3 & 0,5 & 0,75 & 1,0 \\
\hline
\end{tabular}

Do badania kół zębatych opracowano nowe typy sond dotykowych. Zależnie od rodzaju sondy i parametrów układu pomiarowego, głębokość wnikania prądów wirowych zmienia się w granicach $0,08 \div 5 \mathrm{~mm}$.

Pomiary wiroprądowe wykonywano Wirotestem 302 trzema sondami:

- sondą C LF o znacznej głębokości wnikania,

- sondą standardową B MF o średniej głębokości wnikania,

- sondą A HF o niewielkiej głębokości wnikania, stosowaną do kontroli zjawisk powierzchniowych, zwłaszcza naprężeń.

W pierwszym etapie badaniu poddano koło zębate doświadczalne B (38 zębów), z wykrytym mikroskopowo na zębie 4 głębokim pęknięciem. Następnie na badanym kole piłą tarczową diamentową o średnicy $12 \mathrm{~mm}$, grubości $0,1 \mathrm{~mm}$ wykonano nacięcia różnej głębokości (tabl. I). W drugim etapie przebadano wpływ na charakterystykę wiroprądową czasu magazynowania.

\section{Wyniki pomiarów na kole z nacięciami}

Na rysunku 1 przedstawiono charakterystykę wiroprądową koła przed dokonaniem nacięć. Na zębie 4 widoczny jest sygnał spowodowany pęknięciem podczas produkcji.

$\mathrm{Na}$ rysunkach $2 \div 4$ przedstawiono wyniki pomiarów wykonanych sondami o różnej głębokości wnikania.

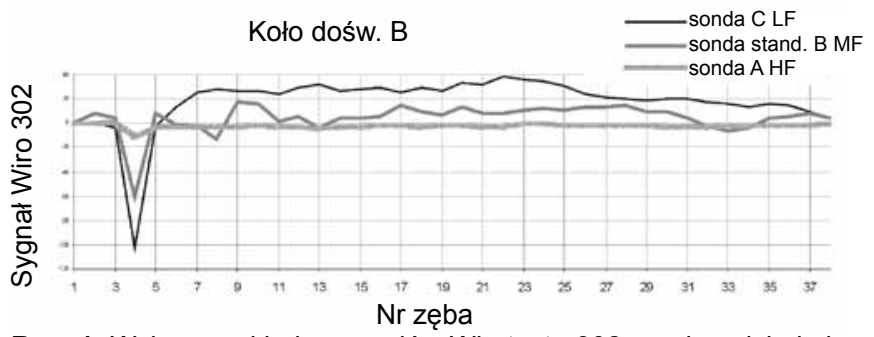

Rys. 1. Wykres rozkładu sygnałów Wirotestu 302 na obwodzie koła doświadczalnego przed wykonaniem nacięć

Fig. 1. Wirotest 302 signal distribution along a circle of experimental gear wheel without the cuts

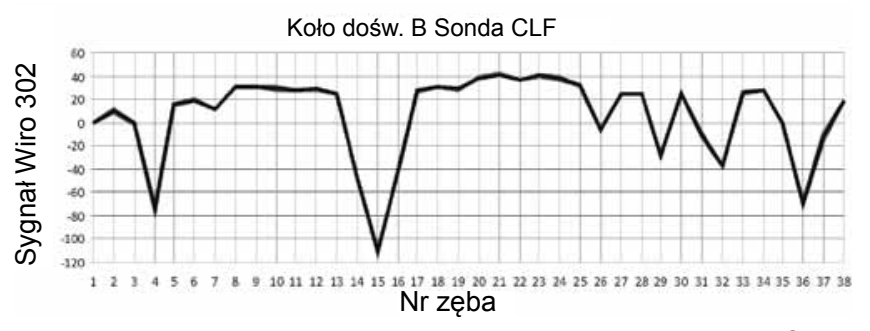

Rys. 2. Wykres rozkładu sygnałów Wirotestu 302 sondą C LF na obwodzie koła doświadczalnego po wykonaniu nacięć

Fig. 2. C LF sonde in Wirotest 302 signal distribution along a circle of experimental gear wheel with the cuts 
$Z$ danych na rysunku 2 wynika proporcjonalność sygnałów Wirotestu 302 do głębokości nacięć. Ubytek materiału spowodowany rzeczywistym pęknięciem oraz nacięciami mechanicznymi powoduje sygnał ujemny. Można wnioskować, że pęknięcie na zębie 4 ma głębokość zbliżoną do nacięcia na zębie 36, czyli ok. $1 \mathrm{~mm}$. Interesujący jest wykres odpowiadający sygnałom z powierzchni (rys. 3). Należy wziąć pod uwagę, że przy wykonywaniu nacięć nastąpił lokalny zgniot materiału, co spowodowało lokalny wzrost naprężeń. Na zębach 14 i 16 widoczne są piki dodatnie (naprężenia spowodowane lokalnymi uszkodzeniami), natomiast na zębie 15 już widać różnicę będącą wynikiem głębokiego ubytku materiału. Zęb 32 i 36 - z nacięciem, przy równoczesnym nieznacznym uszkodzeniu zębów sąsiednich (naprężenia). $Z$ wykresu przedstawiono na rysunku 2 - sonda standardowa wynikają zbliżone wnioski. Uwagę zwraca pik na zębie 26, gdzie obserwacje mikroskopowe ujawniły mechaniczne uszkodzenie powierzchni.

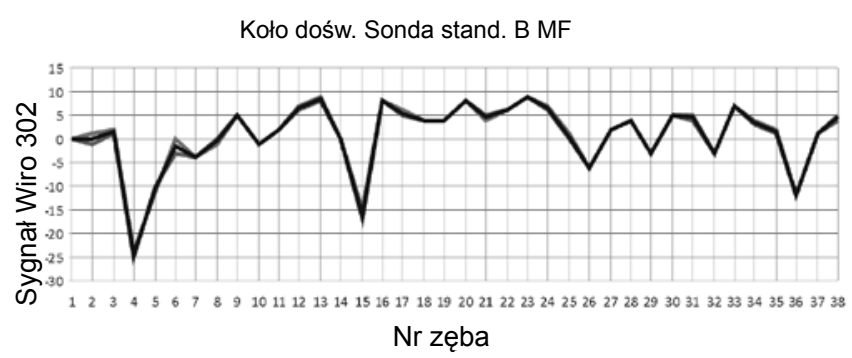

Rys. 3. Wykres rozkładu sygnałów Wirotestu 302 sondą stand. B MF po obwodzie koła doświadczalnego po wykonaniu nacięć

Fig. 3. B MF standard sonde in Wirotest 302 signal distribution along a circle of experimental gear wheel with the cuts

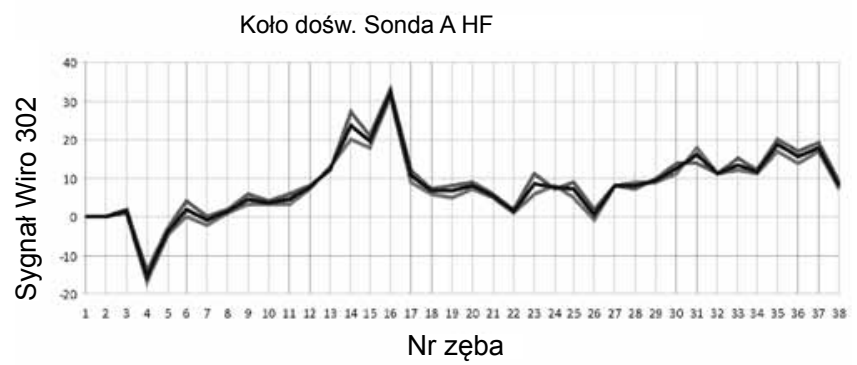

Rys. 4. Wykres rozkładu sygnałów Wirotestu 302 sondą stand. A HF na obwodzie koła doświadczalnego po wykonaniu nacięć

Fig. 4. A HF standard sonde in Wirotest 302 signal distribution along a circle of experimental gear wheel with the cuts

\section{Podsumowanie}

Na podstawie pomiarów, wykonanych sondami o różnej głębokości wnikania, można stwierdzić możliwość odróżnienia sygnałów pochodzących od naprężeń od sygnałów spowodowanych ubytkiem materiału (pęknięciami).

Wykazano możliwość analizy stanu kół po okresie magazynowania - wykrywania zmian ich stanu.

Przewiduje się kontynuowanie badań z uwzględnieniem metody rentgenowskiej ilościowego oznaczania naprężeń w warstwie zahartowanej.
Jak widać z porównania przytoczonych wykresów, sygnał Wirotestu od pęknięć ma charakter ujemny, naprężenia ściskające powodują wzrost sygnału.

\section{Wpływ czasu na zmianę charakterystyki wiroprądowej}

Na rysunkach 5 i 6 pokazano możliwość kontroli zmian struktury i naprężeń kół w funkcji czasu.

Kształt krzywych dla koła 22A wykonanych po 15 miesiącach różni się od początkowego. Pozostaje pik charakterystyczny dla pęknięcia na zębie 24 , stwierdzono natomiast obecność dodatkowego piku na zębie 29. Na podstawie mikrofotografii potwierdzono, że przyczyną jest pojawienie się w badanym obszarze mikropęknięć. Widoczny jest również wzrost naprężeń rozciągających w obszarze między zębami 35 i 41.

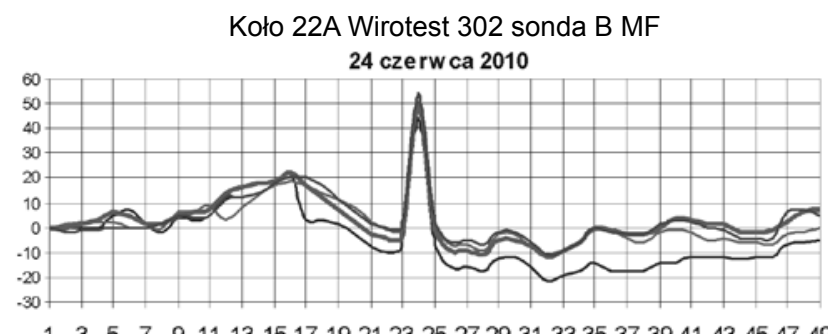

7 Rys. 5. Charakterystyka wiroprądowa koła 22A otrzymano 24 czerwca 2010 r.

Fig. 5. Characteristics of eddy current of 22A gear wheel on 24 June 2010

Koło 22A Wirotest 302 sonda B MF

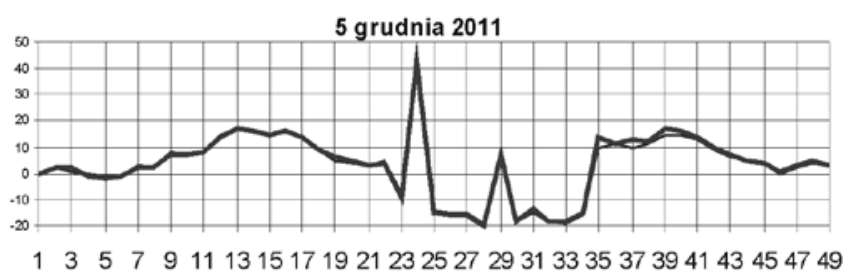

Rys. 6. Charakterystyka wiroprądowa koła $22 \mathrm{~A}$ otrzymana 5 grudnia $2011 \mathrm{r}$.

Fig. 6. Characteristics of eddy current of $22 \mathrm{~A}$ gear wheel on $5 \mathrm{De}-$ cember 2011

Badania wykonane w ramach pracy [2] oraz omawiano w niniejszej pracy potwierdziły tezę o możliwości zastosowania pomiarów układem Wirotest 302 z sondami o zróżnicowanej głębokości wnikania do kontroli jakości kół zębatych - wykrywania imperfekcji strukturalnych i naprężeniowych oraz wykrywania wad w postaci pęknięć. 


\section{Literatura}

[1] Dybiec C., Nakonieczny A., Włodarczyk S.: Praktyczne zastosowanie metody prądów wirowych do pomiaru wielkości i kierunku naprężeń. Mat. 32 KKBN Międzyzdroje 2003.

[2] Babul T., Jończyk S., Samborski T., Włodarczyk S.: Zastosowanie Wirotestów do kontroli kół zębatych. Mat. 40 KKBN. Warszawa 2011.
[3] Zaborowski T.: Zjawiska fizyczne wpływające na naprężenia własne w technologicznej warstwie wierzchniej. Mat. Konf.: Warstwa wierzchnia technologicznie kształtowana, Gorzów Wlkp - Warszawa 2011, s. 204.

[4] Heptner H., Stroppe H.: Magnetyczne i indukcyjne badania metali. Wyd. Śląsk 1972 r. s. 190-191.

\section{Nowości wydawnicze}

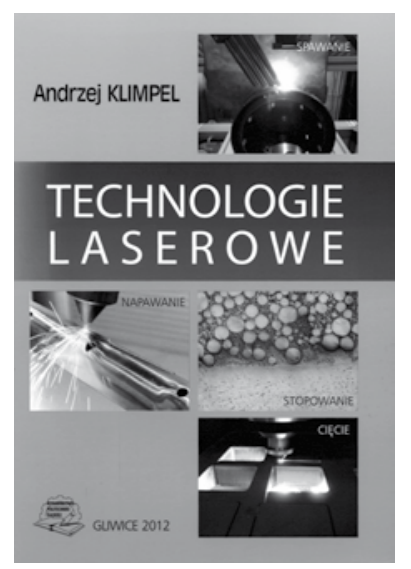

Andrzej Klimpe

Format: B5, oprawa: miękka

Liczba stron: 326

ISBN 978-83-7335-950-5

Wydawnictwo Politechniki Śląskiej, Gliwice 2012
W 2012 r. ukazała się monografia autorstwa profesora dr. hab. inż. Andrzeja Klimpla pt. „Technologie Laserowe - spawanie, napawanie, stopowanie, obróbka cieplna oraz cięcie".

Autor monografii w kolejnych rozdziałach przedstawia podstawy fizyczne promieniowania laserowego, przemysłowe spawalnicze lasery, techniki spawania, napawania i cięcia laserowego.

W rozdziale pierwszym pt. „Podstawy fizyczne promieniowania laserowego", autor zwięźle charakteryzuje istotę, parametry oraz rozwój zastosowań wiązki laserowej i laserów, jak również podkreśla znaczenie doboru parametrów wiąki laserowej (parametrów jakości BPP i TEM, mocy wiązki, kształtu i wymiarów ogniska), jako procesu złożonego i wymagającego wiedzy nie tylko w obszarze urządzeń i technologii, ale również zagadnień inżynierii materiałowej.

Rozdział drugi pt. „Spawalnicze lasery przemysłowe” dotyczy charakterystyki laserów przemysłowych, w tym, gazowych $\mathrm{CO}_{2}$, Nd:YAG, włóknowych, tarczowych i diodowych dużej mocy, oraz porównania podstawowych cech fizycznych i parametrów technicznych laserów spawalniczych.

W dalszej części książki Autor zawarł:

- uwagi ogólne dotyczące analizowanej tematyki podkreślając rolę sterowania komputerowego kształtem i mocą wiązki laserowej, układów CNC pozycjonowania oraz przesyłu wiązki laserowej systemami optycznymi lub światłowodami w zakresie zapewnienia najwyższej jakości przebiegu laserowych procesów technologicznych.

- charakterystykę problemów technologicznych spawania laserowego oraz takim parametrom procesu jak: moc wiązki światła laserowego ciągłego, energia impulsu światła laserowego, czas trwania impulsu, częstotliwość powtarzania impulsu, prędkość spawania (przesuwu wiązki laserowej), kształt toru wiązki wzdłuż linii złącza, długość ogniska wiązki laserowej, kształt i wymiary wiązki laserowej, położenie ogniska wiązki laserowej względem górnej powierzchni złącza, rodzaj i natężenie przepływu gazu ochronnego. Przedstawiono również liczne uwagi praktyczne dotyczące spawania laserowego zróżnicowanych pod względem budowy i materiału elementów konstrukcji wynikające $z$ własnych doświadczeń i danych literaturowych.

- analizę wpływu warunków technologicznych napawania i stopowania laserem Nd:YAG, diodowym, HPDL ROFIN DL 015 i HPDL ROFIN DL 020, $\mathrm{CO}_{2}$ oraz stanu powierzchni podłoża i rodzaju materiału dodatkowego jako drutu CastoMag 45500, proszku ceramicznego MetaCeram 28060, stopu na osnowie kobaltu i drutu proszkowego cermetalowego Ni-WC, proszku krzemu i na osnowie niklu na podłożach ze stali niskostopowej, manganowej, austenitycznej, narzędziowej X37CrMoV5-1 i tytanu technicznego na parametry geometryczne napoin i udział materiału podłoża w napoinie, oraz warunki technologiczne obróbki cieplnej powierzchniowej laserem diodowym HPDL ROFIN DL 015 różnego rodzaju materiałów.

- analizę wpływu technologicznych cięcia i ukosowania laserem gazowym ESAB-Hancock 3-D blach ze stali konstrukcyjnej niskostopowej, rodzaju gazów stosownych do cięcia laserowego różnych materiałów, prezentacji przykładowych parametrów cięcia laserem gazowym $\mathrm{CO}_{2}$ i stałym $\mathrm{Nd}$ :YAG oraz cięcia automatycznego laserem gazowym $\mathrm{CO}_{2}$ różnych materiałów inżynierskich.

Książka jest przeznaczona przede wszystkim dla konstruktorów, technologów oraz specjalistów z obszaru inżynierii materiałowej i dziedzin dotyczących konstruowania i wytwarzania. Ponadto monografia może stanowić cenny materiał dla studentów Uczelni Technicznych studiujących Inżynierię Materiałową, Mechanikę i Budowę Maszyn, Metalurgię, Mechatronikę, Energetykę oraz Zarządzanie i Inżynierię Produkcji, zwłaszcza na Politechnice Śląskiej. 